\section{Case Reports in Gastroenterology}

Case Rep Gastroenterol 2021;15:244-252

DOI: 10.1159/000513145

Published online: February 26, 2021

(C) 2021 The Author(s)

Published by S. Karger AG, Basel

www.karger.com/crg

This article is licensed under the Creative Commons Attribution-NonCommercial 4.0 International License (CC BY-NC) (http://www.karger.com/Services/OpenAccessLicense). Usage and distribution for commercial purposes requires written permission.

\title{
Giant Calculus with More than 100 Small Calculi in Choledochal Cysts
}

\author{
Akshay Bahadur $^{\mathrm{a}}$ Vijay Thakur ${ }^{\mathrm{b}}$ Lovenish Bains $^{\mathrm{c}}$ Prerna Arora $^{\mathrm{d}}$ \\ Yanshul Rathi ${ }^{a} \quad$ Ashish Shukla ${ }^{a}$ \\ ${ }^{a}$ Department of Surgery, Dr. Hedgewar Arogya Sansthan, Delhi, India; ${ }^{b}$ Department of \\ General Surgery, Lal Bahadur Shastri Hospital, Delhi, India; 'Department of Surgery, \\ Maulana Azad Medical College, New Delhi, India; dDepartment of Pathology, Maulana \\ Azad Medical College, New Delhi, India
}

\section{Keywords}

Common bile duct $\cdot$ Choledochal cyst $\cdot$ Giant calculus $\cdot$ Heterotopic pancreas

\begin{abstract}
Giant biliary calculus in the common bile duct (CBD) is rare. Giant calculus of choledochal cyst (CC) is even rarer, and no case of giant calculus of CC with more than 100 calculi has been reported in the indexed literature. We present the case of a $8.0 \times 4.5 \times 4.0 \mathrm{~cm}$ sized giant calculus with $>100$ small calculi in type IVa CCs with heterotopic pancreas in a 45 -year-old male, which is a surprisingly rare occurrence. Magnetic resonance cholangiopancreatography showed multifocal irregular dilatation of intrahepatic biliary radicles with multiple filling defects with a giant calculus in CC with cholelithiasis. The case was successfully managed with open cholecystectomy and choledochotomy with retrieval of 1 giant and more than 100 small calculi with excision of CC with Roux-en-Y hepaticojejunostomy. Histopathological examination (HPE) showed inflamed CC identified with focal areas of surface ulceration with increased fibrosis areas in the wall and few pancreatic acini. A bile duct calculus is defined as "giant" when the size is $5 \mathrm{~cm}$ or more. Stone formation within is the most frequent complication of CC. Most intracystic calculi have been described as soft, earthy, and pigmented in appearance,
\end{abstract}

\begin{tabular}{ll}
\hline & Akshay Bahadur \\
Department of Surgery \\
Dr. Hedgewar Arogya Sansthan \\
Delhi 110032 (India) \\
drakshay@live.com
\end{tabular}




\section{Case Reports in Gastroenterology}

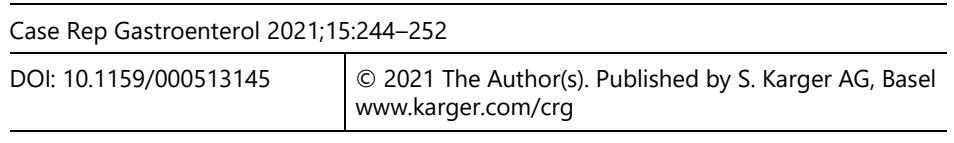

Bahadur et al.: Giant Calculus with More than 100 Small Calculi in Choledochal Cysts

supporting bile stasis as a primary etiologic factor. The only treatment for giant calculus of CBD or CC is surgical. Endoscopic treatment is mostly unsuccessful and open surgery is the treatment of choice due to giant size, increased load of calculus, and presence of calculi in the left and right hepatic ducts.

(C) 2021 The Author(s)

Published by S. Karger AG, Basel

\section{Introduction}

Cystolithiasis and cholecystolithiasis are the most frequent conditions occurring in $70 \%$ of adults with choledochal cysts (CCs) [1]. A bile duct calculus is defined as "large" if it is more than $1.5 \mathrm{~cm}$ in size and as "giant" when it is $5 \mathrm{~cm}$ or more in size [2-4]. Though giant calculus of the gallbladder is common, giant calculus in the common bile duct (CBD) is rare [5]. Only few cases of giant biliary calculus in the CBD measuring $5 \mathrm{~cm}$ or more have been published [2, 3]. Only 1 case of more than 100 biliary calculi in the bile duct has been reported [6]. We report probably the largest giant calculus of CC with more than 100 biliary calculi in CCs with pancreatic acini in the wall of CCs.

\section{Case Report}

Our patient, a 45-year-old male, came to Outpatient Department (OPD) with a history of pain in the right upper quadrant, which was colicky in nature, mild to moderate in severity, and recurrent for the past 15-20 days. The patient also gave a history of discomfort in the same area with nausea off and on, especially after taking heavy meals for the past 4 years. The patient was well nourished, nonicteric, afebrile with a pulse of $80 / \mathrm{min}$ and blood pressure of 110/70 mm Hg. Clinical examination revealed mild tenderness in the right hypochondrium on deep palpation with no rebound tenderness. The remaining examination of the abdomen was unremarkable.

Blood investigations revealed hemoglobin of $15 \mathrm{~g} / \mathrm{dL}$, white cell count of 11,100/cumm with $64 \%$ polymorphs, $30 \%$ lymphocytes, $4 \%$ monocytes, and $2 \%$ eosinophils. Liver function test showed total serum bilirubin of $0.64 \mathrm{mg} / \mathrm{dL}$, AST $18 \mathrm{U} / \mathrm{L}$, and ALT $17 \mathrm{U} / \mathrm{L}$. Renal function test, serum electrolyte, serum glucose, and urine analysis were all normal.

Ultrasonography (USG) revealed a partially distended gall bladder containing multiple calculi in the CBD and CCs with CC of $5.0 \times 8.0 \mathrm{~cm}$ in size with a giant calculus. Magnetic resonance cholangiopancreatography (MRCP) showed gross fusiform dilatation of the CBD throughout its length measuring approximately $4.8 \mathrm{~cm}$, possibly representing CC. A large signal void measuring approximately $4.0 \times 7.6 \mathrm{~cm}$ is seen within the CBD, which is likely a calculus. There was gross dilatation of bilobar intrahepatic biliary radicles (CCs) loaded with multiple calculi within. The gallbladder was distended with multiple calculi in the lumen (Fig. 1).

On exploration, the gall bladder was distended, containing multiple calculi. There was a large CC arising $1 \mathrm{~cm}$ distal to the confluence of the right and left hepatic duct, extending just proximal to the opening of the pancreatic duct, containing a hard calculus and multiple calculi.

\section{Karger'=}




\section{Case Reports in Gastroenterology}

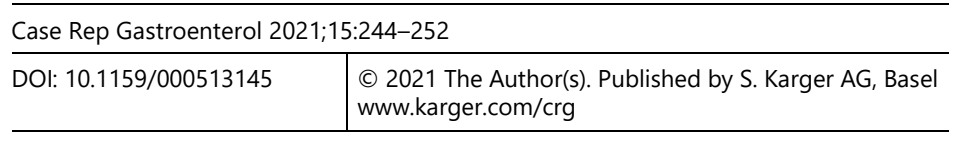

Bahadur et al.: Giant Calculus with More than 100 Small Calculi in Choledochal Cysts

The omentum and duodenum were adherent to the CC. With meticulous and gradual dissection, the surrounding structures were separated; a choledochotomy of approximately $1.5 \mathrm{~cm}$ was made on anterior wall of the CC. The choledochotomy was enlarged due to the giant calculus, which had completely occluded the cyst. The calculus of the size of $8.0 \times 4.5 \times 4.0 \mathrm{~cm}$ was retrieved as a single piece. More than 100 small calculi were also retrieved from extrahepatic and intrahepatic CCs (Fig. 2). Cholecystectomy with excision of extrahepatic CC with Roux-en-Y hepaticojejunostomy was performed. No liver biopsy was performed.

From the 4th postoperative day (POD), clear fluid through the right subhepatic drain was noticed, which was 200-300 mL for the first 2 days and increased to 1,000 mL/day from day 6. Biochemical analysis of the fluid showed more than 20,000 U/L amylase. The patient was kept on total parental nutrition along with octreotide injection $100 \mu \mathrm{g}$ intravenously every 8 hours. Gradually, the daily drain output started decreasing. On the 19th POD, the daily drain output was reduced to less than $50 \mathrm{~mL}$. The patient was again started on entral nutrition. On the 25th POD, the patient was discharged in a satisfactory condition. Histopathology showed chronic cholecystitis with inflamed CC identified with focal areas of surface ulceration with the underlying wall showing presence of areas of increased fibrosis and few pancreatic acini (Fig. 3). The patient is presently doing well at 3 years of follow-up.

\section{Discussion}

A bile duct calculus is defined as giant if it is $5 \mathrm{~cm}$ or more in size [2-4]. Though giant calculus of the gallbladder is common, giant calculus in the CBD is rare [5]. Only few cases of giant biliary calculus in the CBD measuring $5 \mathrm{~cm}$ or more have been published (Table 1) [2-5, $7-15]$. The presence of such a giant calculus without an associated jaundice is rare [14, 15]. Out of a total of 12 cases of giant biliary calculus in the CBD of $5 \mathrm{~cm}$ or larger found in the literature, 6 cases had associated jaundice, 5 cases, including our case, had normal bilirubin, and status of jaundice in 2 cases was not available.

It is reported that in most cases of choledocholithiasis, a solitary calculus is found in the CBD [16]. Walter and Snell [17] reported a solitary calculus in two-thirds of their cases. Robson and Dobson [18] once counted 88 calculi. There is only 1 case, as reported by Judd and Marshall [6], in which more than 100 biliary calculi were found in the bile duct. To our knowledge, no case of giant biliary calculus in confirmed CC nor any case of more than 100 biliary calculi in CC has been reported in the indexed literature to date. We came across such a rare entity of a giant calculus with more than 100 small biliary calculi in CCs.

Stone formation within the CC (cystolithiasis) is the most frequent complication of CC. The prevalence of intracystic calculi ranges from 2 to $72 \%$ in adults [19-21] and is increasing in incidence with age [22]. Most intracystic calculi have been described as soft, earthy, and pigmented in appearance, supporting bile stasis as a primary etiologic factor [21].

Although secondary calculi are the most commonly observed CBD calculi, particularly in Europe and North America, primary calculi are encountered more commonly in Asia [23]. In the West, the majority of CBD calculi are composed of cholesterol calculi that originated from the gallbladder. Less than $10 \%$ of CBD calculi are formed de novo within the CBD. On the other

\section{Karger'=}




\section{Case Reports in Gastroenterology}

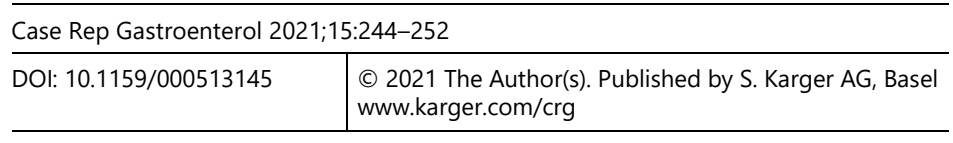

Bahadur et al.: Giant Calculus with More than 100 Small Calculi in Choledochal Cysts

hand, in the East, because of a higher incidence of chronic biliary tree infection and infestation, the occurrence of pigmented calculi is much more common. It is characterized by recurrent cholangitis due to the presence of multiple pigment calculi formed inside the intrahepatic ducts [24].

Heterotopic pancreatic tissue present on the wall of CCs is a very rare entity. Heterotopic pancreas is defined as pancreatic tissue that is not found in direct continuity with the main pancreas [25]. It is difficult to explain embryologically the association of heterotopic pancreatic tissue on the wall of CCs. A possible hypothesis is that there is fetal migration of pancreatic cells into the biliary tree, followed by release of pancreatic enzymes from the heterotopic rest present on the wall, which may result in damage and dissolution of the wall leading to dilatation [25].

MRCP has proved to be an accurate noninvasive imaging method for choledocholithiasis [24], CC, and their associated anomalies [26]. Endoscopic treatment for giant calculus of the CBD is often unsuccessful because of the calculus size, and the treatment is always surgical [4]. Treatment of CC is complete excision of the affected biliary tract with reconstruction by a bilioenteric anastomosis in order to reduce potential long-term complications [27]. Biliary continuity may be established either by a Roux-en-Y hepaticojejunostomy or hepaticoduodenostomy [27]. In our case, open cholecystectomy with excision of extrahepatic CC with Rouxen-Y hepaticojejunostomy was performed.

In conclusion, giant calculus of the CBD is uncommon and giant calculus in CC is rare. Endoscopy has no role in the treatment of giant calculus. The treatment is always surgical, usually by open technique due to giant calculus, increased calculus load, and calculi in proximal ducts. Roux-en-Y bilioenteric anastomosis may be considered as a first line of treatment in cases of giant calculus of CBD/CC, multiple CBD calculi, or recurrent CBD calculi.

\section{Statement of Ethics}

Approval for case reports by the institutional ethics committee is not required. Written informed consent was obtained from the patient regarding publication of this case.

\section{Conflict of Interest Statement}

There are no conflicts of interest to be reported.

\section{Funding Sources}

There was no source of funding.

\section{Karger'=}




\section{Case Reports in Gastroenterology}

\section{Author Contributions}

A.B. conceptualized the manuscript. A.B., V.T., and L.B. reviewed the literature and analyzed the data. A.B. wrote the manuscript with the help of L.B., Y.R., and A.S. A.B. and V.T. performed the clinical examination, surgical treatment, and clinical follow-up. P.A. provided the histopathological examination. A.B., V.T., L.B., P.A., Y.R., and A.S. performed the final review and editing of the manuscript. All authors have read and approved the final version of the manuscript.

\section{References}

1 Weyant MJ, Maluccio MA, Bertagnolli MM, Daly JM. Choledochal cysts in adults: a report of two cases and review of the literature. Am J Gastroenterol. 1998 Dec;93(12):2580-3.

2 Bahuleyan CK. Giant common bile duct calculus. Indian J Surg. 1975;37:82.

3 Jayant M, Dalal AK, Attri AK, Sachdev A. Giant staghorn stone in common bile duct. Indian J Gastroenterol. 2010 Sep;29(5):212.

4 Hajong R, Topno N, Baruah AJ, Khongwar D. Giant staghorn common bile duct calculus. Indian J Gastroenterol. 2012 Dec;31(6):357.

5 Bhattarai SR, Bhattarai A, Tamrakar KK. Giant staghorn common bile duct calculus: a case report. J Chitwan Med Coll. 2019;9(4):72-4.

6 Judd ES, Marshall JM. Gallstones in the common bile duct. Arch Surg. 1931 Aug;23(2):175-81.

7 Okano A, Takakuwa H, Nishio A. Giant stone in the common bile duct. Endoscopy. 2001 Oct;33(10):907.

8 Sharma M, Gupta A, Singal R, Jain R, Khatri A, Sharda P, et al. A rare presentation of common bile duct stone. Oncol Gastroenterol Hepatol Reports. 2016;5(1):29.

9 Ahmed MN, Bhat DP, Zargar HU, Kh an M. Giant common bile duct stone (A case report). J Postgrad Med. 1982;28(4):233-4.

10 Bhat J. Giant Staghorn Common Bile Duct Calculus (A Case Report). J Gastrointest Dig Syst. 2017;07(05):4-5.

11 Bektas H, Duzkoylu Y, Cakar E, Buyukasık K, Colak S. Giant choledochal calculosis: surgical treatment. N Am J Med Sci. 2014 Oct;6(10):536-9.

12 Jarrar MS, Ben Hadj Khalifa MH, Ghrissi R, Ben Mansour I, Hamila F, Elghali A, et al. Giant staghorn common bile duct calculus. Tunis Med. 2016 Jul;94(7):401-3.

13 Hamid R, Bhat NA, Ahmad M, Singh B. Choledochal Cyst (CDC). In: Neri V, editor. Gastrointestinal Surgery. Rijeka: IntechOpen; 2018. https://doi.org/10.5772/intechopen.72938.

14 Hussain A, Jeelani G, Zargar HU, Bhan B. Giant common bile duct calculus. Int Surg. 1977 Sep;62(9):476.

15 Han HJ, Lee JS, Song TJ. Giant common bile duct stone. Cent Eur J Med. 2012;7(1):59-62.

16 Arid I. A Companion in Surgical Studies. 2nd ed. Edinburgh and London; 1949.

17 Walters W. Diseases of the gallbladder and bile ducts. South Med J. 1940;33(4):446.

18 Robson AW, Dobson JF. Diseases of the gall-bladder and bile-ducts, including gall-stones. New York: W Wood; 1904.

19 Nagorney DM, McIlrath DC, Adson MA. Choledochal cysts in adults: clinical management. Surgery. 1984 Oct;96(4):656-63.

20 Chijiiwa K, Koga A. Surgical management and long-term follow-up of patients with choledochal cysts. Am J Surg. 1993 Feb;165(2):238-42.

21 Khandelwal C, Anand U, Kumar B, Priyadarshi RN. Diagnosis and management of choledochal cysts. Indian J Surg. 2012 Feb;74(1):29-34.

22 Matsumoto Y, Uchida K, Nakase A, Honjo I. Congenital cystic dilatation of the common bile duct as a cause of primary bile duct stone. Am J Surg. 1977 Sep;134(3):346-52.

23 Shah KN, Clary BM. Chapter 36A - Stones in the bile duct: Clinical features and open surgical approaches and techniques. In: Jarnagin W, editor. Blumgart's Surgery of the Liver, Biliary Tract and Pancreas. 2-vol set. 6th ed. Philadelphia: Elsevier; 2016. p. 585-603.e3.

24 Lee YT, Sung J. Chapter 33: Choledocholithiasis. In: Baron TH, Kozarek R, Carr-Locke DL, editors. ERCP. Edinburgh: W.B. Saunders; 2008. p. 357-66. 


\section{Case Reports in Gastroenterology}

25 Suzuki K, Uchida T, Nakayama H, Ugajin W, Inaniwa Y, Sugitani M, et al. Heterotopic pancreatic tissue associated with intra- and extrahepatic choledochal cysts. Pathol Int. 1999 Aug;49(8):759-62.

26 Sacher VY, Davis JS, Sleeman D, Casillas J. Role of magnetic resonance cholangiopancreatography in diagnosing choledochal cysts: case series and review. World J Radiol. 2013 Aug;5(8):304-12.

27 Machado NO, Chopra PJ, Al-Zadjali A, Younas S. Choledochal Cyst in Adults: Etiopathogenesis, Presentation, Management, and Outcome-Case Series and Review. Gastroenterol Res Pract. 2015;2015:602591.
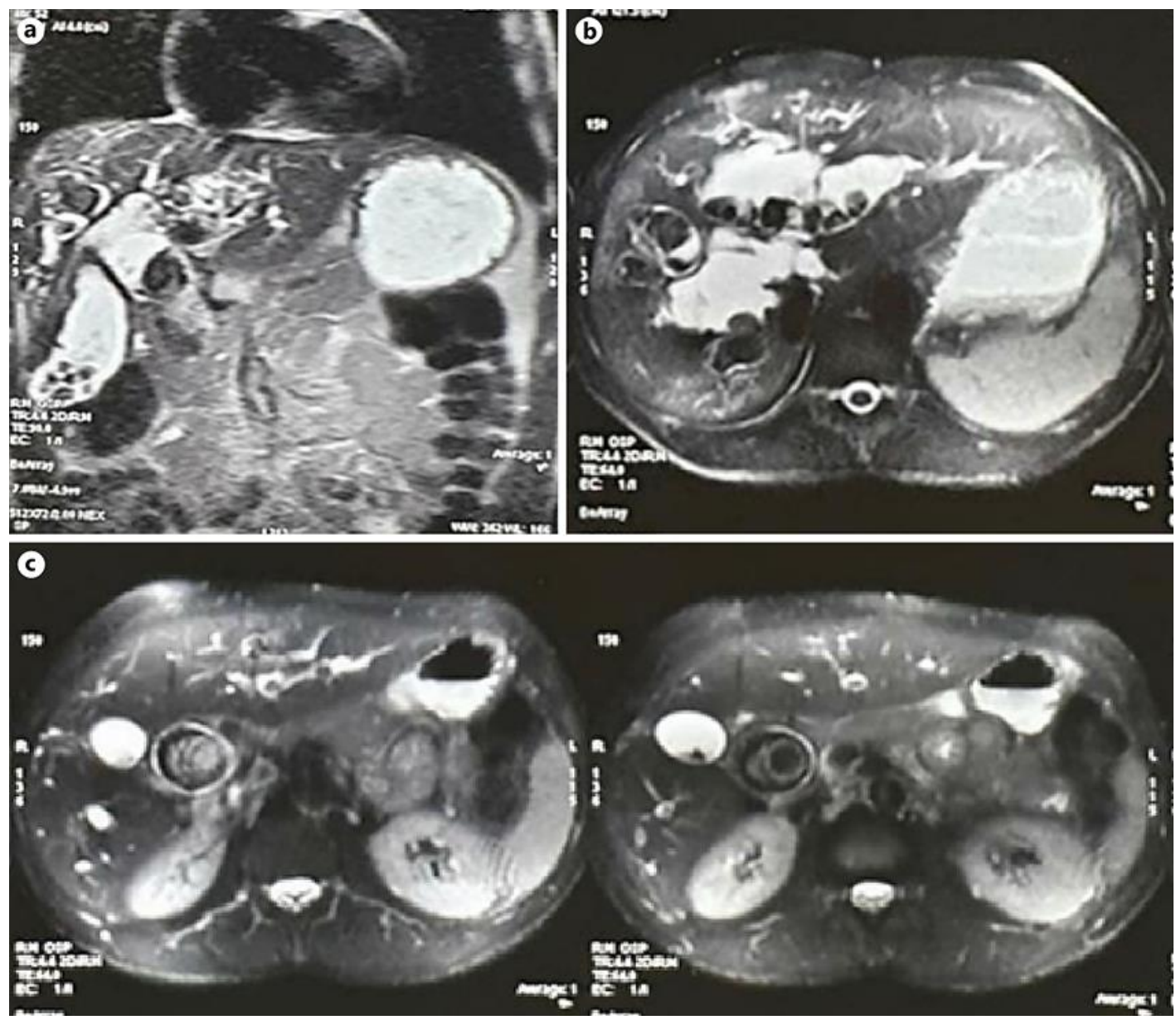

Fig. 1. Magnetic resonance cholangiopancreatography. a Coronal view showing giant calculus within choledochal cyst with cholelithiasis. b Axial image demonstrates intrahepatic choledochal cysts with multiple filling defects within calculi. c Axial view shows giant calculus within choledochal cyst with prominent bilateral intrahepatic biliary radicals (choledochal cysts). 


\section{Case Reports in Gastroenterology}
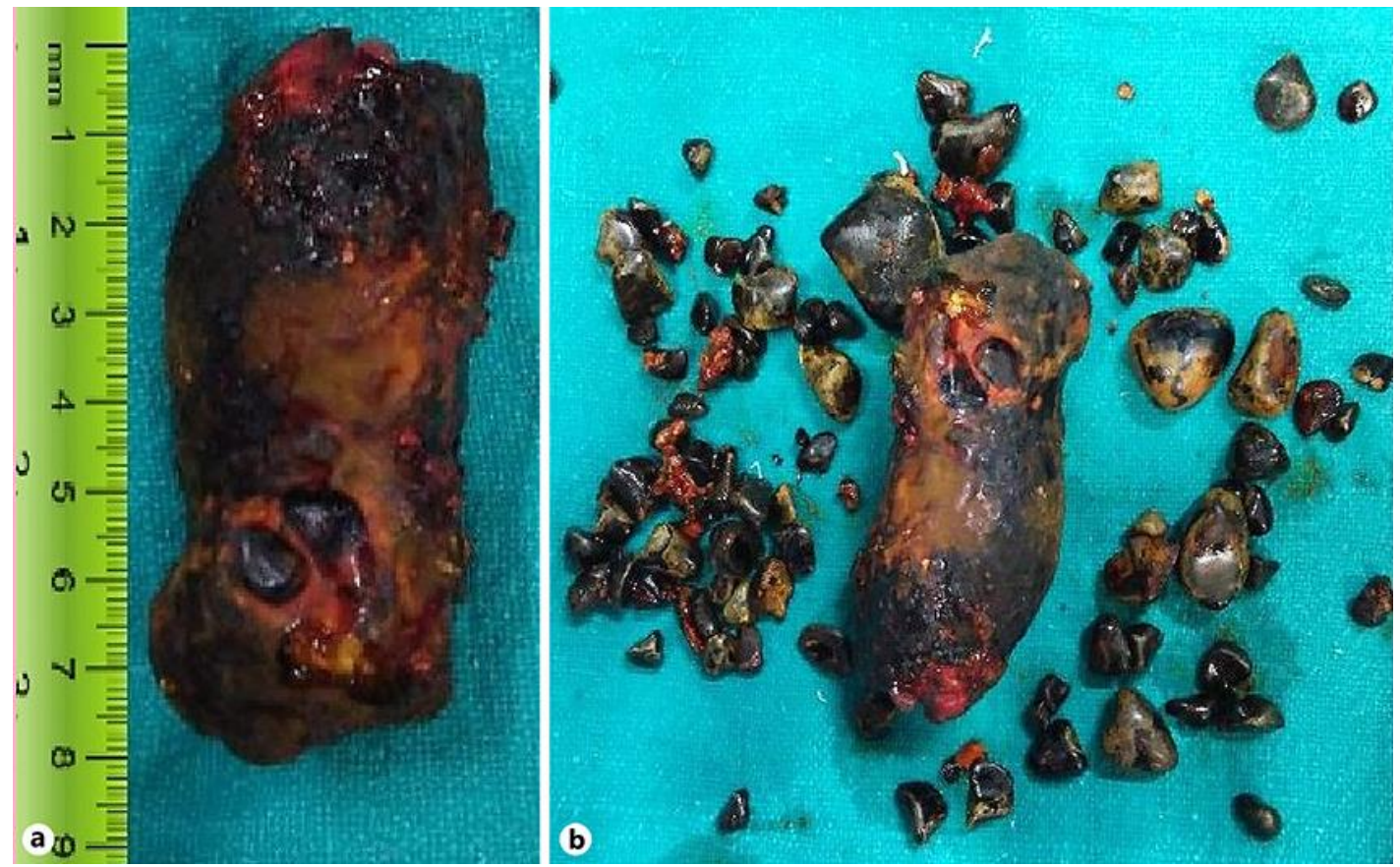

Fig. 2. Calculi retrieved from choledochal cysts. a $8.0 \times 4.5 \times 4.0 \mathrm{~cm}$ sized giant calculus of a extrahepatic choledochal cyst. b Giant calculus with around 100 small calculi of extra- and intrahepatic choledochal cysts. 


\section{Case Reports in Gastroenterology}

Case Rep Gastroenterol 2021;15:244-252

(C) 2021 The Author(s). Published by S. Karger AG, Basel www.karger.com/crg

Bahadur et al.: Giant Calculus with More than 100 Small Calculi in Choledochal Cysts
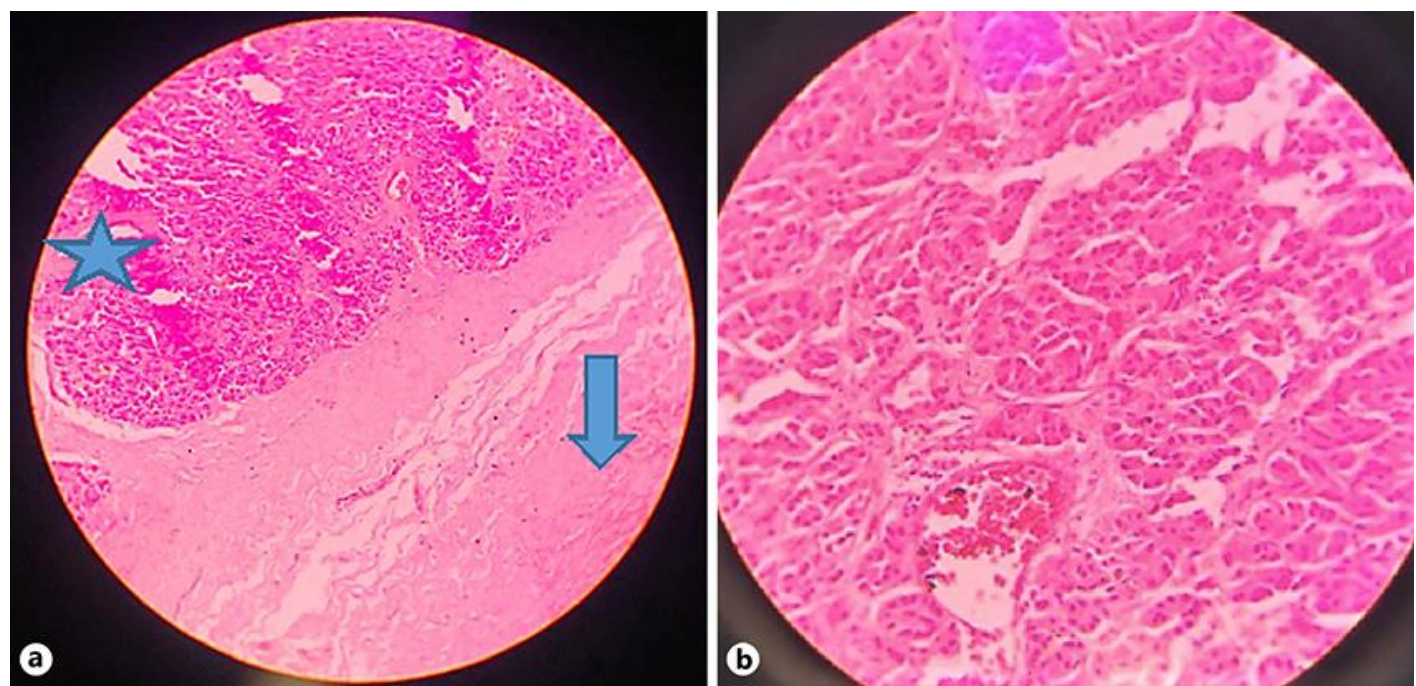

Fig. 3. Histopathological examination of choledochal cyst showing areas of fibrosis (arrow) with pancreatic acini (star) in the wall of a choledochal cyst $(\times 200)$ (a) and pancreatic acini in the wall of a choledochal cyst $(\times 400)$ (b). 


\section{Case Reports in Gastroenterology}

\begin{tabular}{l|l}
\hline Case Rep Gastroenterol 2021;15:244-252 \\
\hline DOI: 10.1159/000513145 & $\begin{array}{l}\text { @ 2021 The Author(s). Published by S. Karger AG, Basel } \\
\text { www.karger.com/crg }\end{array}$ \\
\hline
\end{tabular}

Bahadur et al.: Giant Calculus with More than 100 Small Calculi in Choledochal Cysts

Table 1. Details of giant biliary calculus of $5 \mathrm{~cm}$ or more of the CBD/CC reported to date

\begin{tabular}{|c|c|c|c|c|c|c|c|}
\hline No. & Authors [ref.], year & $\begin{array}{l}\text { Age, } \\
\text { years }\end{array}$ & Sex & Number and size of calculus & Jaundice & $\begin{array}{l}\text { Location of } \\
\text { calculus }\end{array}$ & Treatment \\
\hline 1 & Bhat [10], 2017 & 38 & $\mathrm{~F}$ & $\begin{array}{l}11.5 \times 4 \mathrm{~cm} \\
\text { Single giant staghorn calculus }\end{array}$ & Present & In CBD & $\begin{array}{l}\text { Open cholecystectomy, } \\
\text { choledochotomy, and T-tube } \\
\text { drainage }\end{array}$ \\
\hline 2 & Bektas et al. [11], 2014 & 59 & $\mathrm{~F}$ & $\begin{array}{l}11 \times 4.1 \mathrm{~cm} \\
\text { Single giant calculus }\end{array}$ & Absent & In CBD & $\begin{array}{l}\text { Open cholecystectomy, T-tube } \\
\text { choledochostomy, and } \\
\text { choledochodudenostomy }\end{array}$ \\
\hline 3 & Jarrar et al. [12], 2016 & 65 & & $\begin{array}{l}9 \times 4.5 \mathrm{~cm} \\
\text { Single giant calculus }\end{array}$ & Present & In CBD & $\begin{array}{l}\text { Open cholecystectomy, } \\
\text { choledochotomy }\end{array}$ \\
\hline 4 & Jayant et al. [3], 2010 & 65 & M & $\begin{array}{l}9 \times 4 \mathrm{~cm} \\
\text { Calculus in two pieces from CBD }\end{array}$ & Absent & In CBD & $\begin{array}{l}\text { Open cholecystectomy, } \\
\text { choledochotomy, and } \\
\text { choledochodudenostomy }\end{array}$ \\
\hline 5 & Bhattarai et al. [5], 2019 & 47 & M & $\begin{array}{l}9 \times 3 \mathrm{~cm} \\
\text { Single large calculus }\end{array}$ & Present & $\begin{array}{l}\text { In CBD and both } \\
\text { hepatic ducts }\end{array}$ & $\begin{array}{l}\text { Open cholecystectomy, } \\
\text { choledochotomy, and T-tube } \\
\text { drainage }\end{array}$ \\
\hline 6 & $\begin{array}{l}\text { Bahadur et al. (present case), } \\
2021\end{array}$ & 45 & M & $\begin{array}{l}8 \times 4.5 \times 4 \mathrm{~cm} \\
\text { One giant calculus with } \\
>100 \text { small calculi }\end{array}$ & Absent & In CC & $\begin{array}{l}\text { Open cholecystectomy, } \\
\text { excision of CC, and Roux-en-Y } \\
\text { hepaticojejunostomy }\end{array}$ \\
\hline 7 & Ahmed et al. [9], 1982 & 70 & M & $\begin{array}{l}8.5 \times 3.5 \mathrm{~cm} \\
\text { Single giant calculus }\end{array}$ & Present & In CBD & $\begin{array}{l}\text { Open cholecystectomy, } \\
\text { choledochotomy, and T-tube } \\
\text { drainage }\end{array}$ \\
\hline 8 & Hussain et al. [14], 1977 & NA & NA & $\begin{array}{l}8 \times 2 \mathrm{~cm} \\
\text { Single giant calculus }\end{array}$ & Present & In CBD & $\begin{array}{l}\text { Not mentioned } \\
\text { Open* }\end{array}$ \\
\hline 9 & Hajong et al. [4], 2012 & 48 & $\mathrm{~F}$ & $\begin{array}{l}8 \times 6 \mathrm{~cm} \\
\text { Single giant calculus }\end{array}$ & Present & $\begin{array}{l}\text { In CBD and both } \\
\text { hepatic ducts }\end{array}$ & $\begin{array}{l}\text { Open cholecystectomy, } \\
\text { choledochotomy, and } \\
\text { hepaticojejunostomy }\end{array}$ \\
\hline 10 & Han et al. [15], 2012 & 72 & $\mathrm{~F}$ & $\begin{array}{l}7.5 \times 4.0 \times 4.0 \mathrm{~cm} \\
\text { Single giant calculus }\end{array}$ & Absent & In CBD & $\begin{array}{l}\text { Open cholecystectomy, } \\
\text { choledochotomy, CBD partially } \\
\text { excised, and T tube }\end{array}$ \\
\hline 11 & Bahuleyan [2], 1975 & 38 & $\mathrm{~F}$ & $\begin{array}{l}6.5 \times 3 \mathrm{~cm} \\
\text { Single giant calculus }\end{array}$ & NA & In CBD & $\begin{array}{l}\text { Not mentioned } \\
\text { Open* }\end{array}$ \\
\hline 12 & Okano et al. [7], 2001 & NA & NA & $\begin{array}{l}5 \times 5 \mathrm{~cm} \\
\text { Single giant calculus }\end{array}$ & NA & In CBD & Open laparotomy \\
\hline 13 & Sharma et al. [8], 2016 & 55 & $\mathrm{~F}$ & $\begin{array}{l}5 \times 3 \times 4 \mathrm{~cm} \\
\text { Single giant calculus }\end{array}$ & Absent & In CBD & $\begin{array}{l}\text { Open cholecystectomy, } \\
\text { choledochotomy, and T-tube } \\
\text { drainage }\end{array}$ \\
\hline
\end{tabular}

